\title{
The Value of Hard Work Embodied in the Novel Mata dan Manusia Laut by Okky Madasari
}

\author{
Luvi Kurnia Permana ${ }^{1}$, Sarwiji Suwandi ${ }^{2}$, Atikah Anindyarini ${ }^{3}$ \\ ${ }^{1,2,3}$ The postgraduate thesis of Sebelas Maret University, Indonesia \\ Luvikurniapermana@student.uns.ac.id
}

\begin{abstract}
This study aims at describing the character education values embodied in the novel Mata dan Manusia Laut by Okky Madasari. The novel is chosen due to the character values that can be a reflection of students to apply in daily life. As the object of the study is the stories of this novel which contains the character education values. This study is a descriptive qualitative research in which the data in this study are in the form of words. The data used in the form of a narrative dialogue between characters in the novel. The technique used is the content analysis method. For the data validity of this research uses theory triangulation, method triangulation, and data triangulation. The data analysis technique used is the analysis of the Flow model by Miles and Huberman (2012) through the stages of data reduction, data presentation, as well as withdrawal conclusions. The theory of character education values refers to the Thomas Lickona theory which consists of ten character education values. However, this study is more focused on the value of hard work. The results of this study show that regarding the character education values, novel Mata dan Manusia Laut by Okky Madasari gives examples as well as description especially for the value of hard work which contains eleven values quoted from the novel. Also, the novel Mata dan Manusia Laut by Okky Madasari is representative enough as literacy learning, especially for a novel containing character education.
\end{abstract}

Keywords

Nbvel; character education; Mata danManusialaut

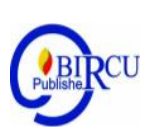

\section{Introduction}

Literature is a reflection of a socio-cultural condition of the nation that must be passed on to the young generation (Salahudin, 2018: 155). It has a serve as a reinforcement of the emergence of a movement for change in society, as well as the rise of a nation towards a better, fostering love for the motherland, and as a source of inspiration and motivation for moral strength for a cultural change from a state of decline and colonization to make an independent state. One of the literary works that can be used to awaken the character values is a novel.

The novel is a work of fiction that reveals aspects of humanity in the way of deeper and finely presented (Semi, 1993: 32). It also illustrates the style, ideas, inspiration and existence and behavior in people's lives. These are found by the existence of character values that are reflected in each character while each of them is built with diverse characters. Based on this emphasize, the study is chosen to discuss the character education values built in the main character.

The research that is relevant to this study is embodied in the novel Nilai Pendidikan Karakter Kerja Keras dalam Novel 2 by Donny Dhirgantoro which employs the value of hard work using descriptive methods with qualitative forms. The technique of collecting data is documentary studies by studying literature. The study is done by clarifying the parts that are 
the object of research, especially the character education values that is hard work. The instrument of the study is the researcher himself. The data analysis technique in research is content analysis. Regarding to the value of hard work the results of the study show the following: (1) the character of work diligently; (2) the character of work earnestly; (3) the character of strength and confidence; (4) the character of manipulates the perceptions of those who doubt it by working hard; (5) the character of the spirit of fighting for life; (6) the character of takes time seriously; (7) the character of passionate; and (8) the character of spirit and unyielding (Sulastri, 2017: 156).

The novel entitled Mata dan Manusia Laut by Okky Madasari is one of the children's best-seller novel. The story of the novel tells about the struggle of children who live on the island of Sama, located in Southeast Sulawesi. On the islands which are home to sea-men, there is a child named Bambulo. He is one of the children who can dive in the sea with no equipment in a depth of about three meters from the seabed. In Kaledupa that is also located in Southwest Sulawesi has a most-wanted celebration especially by the entire community of the island of Sama. At the celebration brought Bambulo to a beautiful child from the capital city named Matara. Since both Bambulo and Matara have high curiosity, they decided to finally sail the ocean. Oceans have a rhythm and rules that everyone must get into. As there was no other companion to sail the ocean and Bambulo has neglected its fact about the oceans, they both then brought into a disaster as well as an amazing adventure.

The character education values employed in the novel entitled Mata dan Manusia Laut by Okky Madasari is one of the reasons used by the researcher to understand aspects of the values. The researcher consider that there are so many character education values, especially the value of hard work embodied in the story of the novel. The character values are representative to evoke the character values of students to be used as teaching material. Also, the character education values especially the value of hard work in the novel can be applied in the students' daily.

\section{Review of Literature}

\section{The Character Education Value of Hard Work}

Education is all the effort to realize and advance character, mind, and body to be able to advance life in harmony with nature and society. The main purpose of character education is to facilitate the strengthening and development of the character education values, to realize the behavior of children who have good character when they are both in the school and the family environment. Character education requires modeling and learning from a younger age to adults to form and build good character for students (Supranoto, 2015: 38).

The conceptualizes the value of character education with regard to moral knowledge, moral feeling, and moral behavior. Moral knowledge includes moral awareness, knowledge of moral values, knowledge of perspectives, moral thinking, decision making, personal knowledge. Furthermore, moral feelings include conscience, self-esteem, empathy, loving good things, self-control, humility. Of the two exposures created a moral action including competence, desires, and habits (Septiadi, 2019).

Adisusilo (2012: 36) described that instilling character values to students as formulated in the 2013 Curriculum was the first step to improve educational goals in Indonesia. In line with this, Citra (2012: 238) said that character education is a system of instilling character values towards school members consisting of various components, such as knowledge, 
awareness or willingness, and actions to carry out these values, both towards God Almighty, oneself, others, and the environment so that it supports to become a better person.

The learning implementation of the character education values refers to the theory by Thomas Lickona (1992: 54); stated that it is better to have a curriculum base that contains character values and is integrated into subjects to be delivered to students. In character education delivered in schools all stakeholders such as the components of education namely curriculum content, learning processes, school management, implementation of activities, empowerment of infrastructure, funding and work ethics throughout both the members of the school and the school environment must be involved (Citra, 2012: 239). Also, schools are required to play their roles and responsibilities to instill and develop all good values and help students shape and build their character with these values.

Character values consist of ten virtues, as the following: (1) wisdom; (2) justice; (3) fortitude; (4) temperance; (5) love; (6) positive attitude; (7) hard work; (8) integrity; (9) blessed; and (10) humility (Lickona, 2016: 16). Of the ten character virtue values the researcher focus on the value of the seventh character that is hard work.

The character value of hard work includes initiative, perseverance, goal setting and ingenuity which is reflected in the main character. Elfindri (2012: 102) mentioned that hard work is the character owned by a person who is not easily discouraged, so is having a strong will in trying to achieve his goals and ideals. Meanwhile, Hidayatullah (2010: 29) revealed that hard work is the ability to devote and mobilize all effort and sincerity, as well as the potential possessed day by day until the goal is reached.

\section{Research Method}

This study is descriptive qualitative research. As the object of this study are the stories of the novel entitled Mata dan Manusia Laut by Okky Madasari which employs content analysis. This novel was published by PT Gramedia Pustaka in 2019 with a page of 232. The data in this study are in the form of narration and using dialogue between characters. Data validity uses theory triangulation, method triangulation, and data triangulation. As revealed by Miles and Huberman (2012), the flow analysis for the data analysis techniques is done through the stages of data reduction, data presentation, and withdrawal conclusions.

\section{Discussion}

As the focus of research is the value of hard work embodied in the novel Mata dan Manusia Laut by Okky Madasari based on the character education theory revealed by Thomas Lickona. According to the theory, there is eleven value of hard work found as the following.

"Biasanya ia hanya mendapat upah setiap kali membantu bapaknya bekerja. Tapi kini, ia bisa mendapatkan semua dari ikan yang ditangkapnya." (NMDML, 2019: 31)

"He usually gets paid by his father every time he helps him to finish work, but he is now earning money from the fish he catches every day." (NMDML, 2019: 31)

In the above quotation, we know that the value of hard work does exist in Bambulo's character. Bambulo is very eager to find fish in the atoll to get what he desires. At first, he felt lazy to reach the atoll since it is hard to reach and need a longer time, but his father keeps telling him to go. He said that Bambulo could sell any fish he caught to buy whatever he wants. At last, Bambulo fits as a fiddle to do that. 
"Di dalam air, tubuh Bambulo meluncur dan bergerak lincah dengan tombak yang siap diayunkan dan dihujamkan, mendekati ikan-ikan yang bisa dijual di pasar atau setidaknya bisa untuk ia makan." (NMDML, 2019: 35)

"Bambulo's body glides and moves swiftly with spears on his hand ready to be swung and stabbed to the fish that can be sold in the market or to eat." (NMDML, 2019: 35)

In the above quotation, there is the value of hard work embodied in the main character, namely Bambulo. He is always passionate about finding fish on the atoll. The more fish he gets, the happier he is. The more fish he gets will give him more money so he can buy what he wants.

"Dengan satu kali hunjaman, ikan-ikan sebesar pahanya akan tunduk, terkapar dan pasrah. Bambulo lalu naik ke permukaan, melempar hasil tangkapannya ke kapal, lalu kembali menyelam." (NMDML, 2019: 36)

"Fish as big as their thighs will bow, fall apart and surrender with one fell swoop. Bambulo then rose to the surface, threw his catch onto the ship, then returned to diving."(NMDML, 2019: 36)

The above quotation states the value of hard work possessed by Bambulo. The fish he caught is more than enough to be sold in the market, but Bambulo is excited to find fish in the atoll.

"Jika Bambulo biasanya berhenti di kedalaman lima puluh meter, kini ia sengaja melanjutkan hingga mencapai seratus meter." (NMDML, 2019: 41)

"Bambulo usually dives at a depth of fifty meters maximum, but now he deliberately continues to reach one hundred meters." (NMDML, 2019: 41)

The above quotation shows that Bambulo is a hard-worker. Bambulo is the best kid at swimming and diving on the island of Sama. Sama's people then call him a sea-man because of his skill at both swimming and diving. Bambulo is also very persistent when he dives so he can reach the depth that is increasing day by day. Due to his skill and his persistent as well, Bambulo won the diving competition with a depth of almost one hundred meters from the seabed.

"Sejak itu, Bambulo makin bersemangat menyelam. Kian lama kian dalam." (NMDML, 2019: 42)

"Since then, Bambulo has become even more passionate about diving. Increasingly more and more deeply. "(NMDML, 2019: 42)

The above quotation reflects the character value of hard work possessed by Bambulo. Since Bambulo gets used to diving at a depth of one hundred meters, he increasingly excited and tried to practice more until he could dive with a depth of more than one hundred meters. People in Sama and the tourists who were around when Bambulo dive were amazed by his great skill and intelligence.

"Meski begitu, kakinya yang terus menendang-nendang ke bawah membuatnya tetap bisa mengapung." (NMDML, 2019: 94)

"Even so, her legs that keep kicking her down make her float." (NMDML, 2019: 94)

The value of hard work does not only belong to the main character that is Bambulo, but the other character does. Matara, Bambulo's friend he met at the celebration, requires this value. The above quotation shows that the value of hard work possessed by Matara. Matara at first could not float on the sea but she kept follow Bambulo's advice and practiced it. Matara kept trying and following what Bambulo said until she became to float. This reflected that Matara is not to yield an inch to reach the goal she set. 
"Dengan bersusah payah terutama bagi Matara mereka berhasil mendekat ke sampan." (NMDML, 2019: 95)

"With great difficulty especially for Matara they succeeded in getting close to the canoe." (NMDML, 2019: 95)

In the above quotation, we know that the value of hard work reflected on what both Batara and Bambulo have done. When they sailed the ocean for the first time, they were thrown from the canoe but were still trying to get back to the canoe and continued their journey. As the first incident happened, the second was by the Bambulo's body that is too small to hold Matara's body and this caused them to sink in the sea. Matara realized what just happened and she kept trying to catch the canoe even she did it by herself.

"Matara meraih pinggiran sampan. Bambulo menahan sampan agar tak terbalik. Lalu

Matara menekan sampan dengan kedua tangannya hingga pantatnya terangkat.

Kemudian ia naikkan satu per satu kakinya dan ... berhasil!" (NMDML, 2019: 96)

"Matara tried to grab the edge of the canoe. Bambulo held the canoe from tipping over. Matara then pressed the canoe with both hands until her bu

ttocks were lifted. Then she lifted one by one his feet and ... voilà! "(NMDML, 2019: 96)The above quotation shows that Bambulo and Matara have the value of hard work. Matara did not ask for Bambulo's help to get on the canoe as she fear of not maintaining balance and drowning again to the sea. While the situation was getting dark as the waves about to crash onto them, Matara asked for a help and they finally helped each other. They could ride the canoe and continue their journey. After all, she felt relieves and proud of her hard work to get through it.

"Ia terus berusaha melawan arus yang menggulungnya. Ia terus mempertahankan kesadaran dan kontrol dirinya. Ia terus berenang, terus menyelam.” (NMDML, 2019: 107)

"He kept trying to go against the wave that was crashing onto him. He continued to maintain awareness and control himself. He continued to swim and to dive. "(NMDML, 2019: 107)

The above quotation shows the value of hard work possessed by Bambulo. He was repeatedly dragged, rolled up, and adrift in the sea. Although Bambulo did not feel good because of the waves being crushed due to his treatment against the commands of the ancestors, he continued the journey. During his journey, he always tried to calm down and continue to swim and dive to conquer the sea until it reached the atoll.

"Bambulo menarik tubuh Matara ke permukaan. Kedua anak itu bersusah payah kembali ke gubuk." (NMDML, 2019: 109)

"Bambulo pulled Matara's body to the surface. The two children struggled to hit the hut. "(NMDML, 2019: 109)

The above quotation requires the value of hard work. On their journey, Bambulo and Matara were constantly hit by trials. Matara was half-conscious and helpless because of the waves. While she could not do anything, Bambulo tried to help by pulling Matara's body to the mainland.

"Bambulo dan Matara mencari cara meninggalkan Masalembo dan pulang ke rumah mereka.” (NMDML, 2019: 194)

"Bambulo and Matara sought to leave Masalembo and return to their homes." (NMDML, 2019: 194)

The above quotation describes the value of hard work reflected by what Bambulo and Matara have done. They rolled the waves until stranded on the island of Masalembo, a very 
high-risk island, It is very hard to get through, but they finally succeed to return home. Bambulo and Matara were assisted by Masalembo's people down each road to get out of Masalembo and return to their homes, on the island of Sama.

\section{Conclusion}

A good character needs to be delivered in the very beginning process of learning. To get what we called as a successful learning process on forming as well as maintaining good character especially for the student also needs support from partial parts, such as school, family, and the community. The novel as a literary work is represented to be used as teaching and learning material in schools especially to build the good characters. In line with this, the study chose the novel entitled Mata dan Manusia Laut by Okky Madasari which employs the character education values especially for the value of hard work reflected by the main character, namely Bambulo. The results of the study found eleven character education values that is hard work that representative to be used as examples of students' role models in daily. Also, the character values embodied in the novel Mata dan Manusia Laut by Okky Madasari are relevant to be used as teaching material to deliver to the student. In this regard, researchers hope that literary works in the form of novels are good to be used for the material of teaching and learning as long as the good character fits the student based on the stories selected.

\section{References}

Adisusilo, S.J.R. (2012). Pembelajaran Nilai Karakter. Depok: Raja Grafindo Persada.

Citra, Y. (2012). Pelaksanaan Pendidikan Karakter dalam Pembelajaran. Jurnal Pendidikan Khusus 1(1), 237-249.

Elfindri, H.L., et al. (2012). Pendidikan Karakter: Karakter, Metode dan Aplikasi untuk Pendidik dan Profesional. Jakarta: Baduose Media.

Hidayatullah. (2010). Pendidikan Karakter: Membangun Peradaban Bangsa. Surakarta: Yuna Pustaka.

Lickona, T. (1992). Educating for Character, How Our Schools Can Teach Respect and Responsibility. New York: Bantam Books. . (2012). Character Matters. Jakarta: Bumi Aksara.

Miles, M.B, and Huberman, A.M. 2012. Analisis Data Kualitatif. Jakarta: UI Press.

Salahudin, A. (2018). Internalisasi Pendidikan Karakter melalui Pembelajaran Sastra. Bandung. Jurnal I'Tibar 6(11), 149-166.

Semi, A. (1993). Ancangan Semiotika. Bandung: Angkasa.

Septiadi, H. N., Andayani \& Wardani, N. E. (2019). Planting Base Value of Hardworking Character Education through Ulid Novel. Budapest International Research in Linguistics and Education Sciences (BirLE) Journal, 36-44

Sulastri, S. 2017. Nilai Pendidikan Karakter Kerja Keras dalam Novel 2 Karya Donny Dhirgantoro. Jurnal Pendidikan Bahasa 6(2), 156-168.

Supranoto, H. (2015). Implementasi Pendidikan Karakter Bangsa dalam Pembelajaran SMA. Jurnal Pendidikan Ekonomi UM Metro 3(1), 36-49. 